\title{
Reversal of symptomatic antipsychotic-induced hyperprolactinemia with addition of aripiprazole
}

\author{
Paraskevi Kotorki ${ }^{2}$, Parthena Pelka ${ }^{1}$, Christina Leotsakou', Aikaterini Kalogeropoulou', Markella Fiste', \\ Georgios Vagionis ${ }^{3}$, Anastasia Roussi ${ }^{1}$, Periklis Paterakis $^{1}$ \\ From $1^{\text {st }}$ International Congress on Neurobiology and Clinical Psychopharmacology and European \\ Psychiatric Association Conference on Treatment Guidance \\ Thessaloniki, Greece. 19-22 November 2009
}

\section{Background}

Hyperprolactinemia is a well-recognized adverse effect of treatment with antipsychotic medication. From the second generation antipsychotics amisulpride, risperidone and paliperidone cause marked elevation in serum prolactin levels. Aripiprazole lowers serum prolactin below placebo when used as a single agent and as an adjunctive treatment has been shown, though not consistently, to improve antipsychotic-induced hyperprolactinemia. It may bind to the dopamine receptor more robustly and act as a dopamine receptor agonist in an antipsychotic-induced hypodopaminergic state. We report two cases of successful treatment of risperidoneand amisulpride-induced hyperprolactinemia and amenorrhea by addition of aripiprazole. This strategy was chosen over administration of an adjunctive dopamine agonist or discontinuation of treatment and a switch to a different antipsychotic agent to avoid clinical deterioration.

\section{Materials and methods}

\section{Case 1}

Ms M, a 35-year-old woman, had an eight-year history of DSM-IV paranoid schizophrenia with one previous compulsory admission. She was involuntarily admitted to our hospital for her third and very severe episode. She was successfully treated on our ward with $800 \mathrm{mg}$ of amisulpride, which was the second trial of antipsychotic. She was discharged after almost 3 months. Amisulpride was gradually reduced to $400 \mathrm{mg}$ after 6 months of treatment. The patient had developed amenorrhea which continued even after lowering the dose of amisulpride, something consistent with the existing data. It was the patient's decision not to discontinue amisulpride as it was very effective for her psychiatric symptoms, especially for her positive symptoms. She had gained insight and was scared about "voices and peculiar ideas coming back". Gradually, $10 \mathrm{mg}$ of aripiprazole were added, and after 12 weeks she regained menstruation and prolactin levels fell (from $81 \mathrm{ng} / \mathrm{ml}$ under amisulpride to $28 \mathrm{ng} / \mathrm{ml}$ ). The patient remained clinically stable.

\section{Case 2}

Ms E, a 30-year-old woman, had a four-year history of DSM-IV paranoid schizophrenia with no previous admission. She was involuntarily admitted to hospital for her third episode and was effectively treated with risperidone $6 \mathrm{mg}$. Risperidone was reduced to $4.5 \mathrm{mg}$ two months after discharge. The patient had developed amenorrhea which continued 6 months after lowering the dose of risperidone. Aripiprazole $10 \mathrm{mg}$ was gradually added. After 13 weeks she regained menstruation and prolactin levels fell (from $95 \mathrm{ng} / \mathrm{ml}$ under risperidone to $25 \mathrm{ng} / \mathrm{ml} \mathrm{65 \% )}$. The patient remained clinically stable.

\section{Results}

Both subjects were clinically stable and there was a high potential risk for relapse due to their history. This led us to the addition of aripiprazole which successfully improved hyperprolactinemia. Treatment was safe and well-tolerated. Both patients regained their menstrual periods in more than 8 weeks, a time period that was previously reported. It appears that aripiprazole is effective in normalizing prolactin in some patients and this could become a treatment of choice.

\footnotetext{
${ }^{2} 1$ st and 5th Department, Dromokaition Psychiatric Hospital, Athens, Greece
} 


\section{Conclusions}

When aripiprazole is co-administed with risperidone or sulpiride, it may bind to the dopamine receptor more robustly and act as a dopamine receptor agonist in an antipsychotic-induced hypodopaminergic state. It appears that aripiprazole is effective in normalizing (or partially normalizing) prolactin in some patients and reversing the clinical side effects without serious side effects or sacrificing psychopathology, and this could become a treatment of choice. Contrary to these findings, Paulzen and Gründer reported a lack of an expected decrease of serum prolactin levels by adding aripiprazole in patients treated with amisulpride. A possibility of partial, but not total restoration of symptomatic hyperprolactinemia might be due to the relatively low aripiprazole dose $(10 \mathrm{mg} /$ day). Receiving aripiprazole $15-20 \mathrm{mg} /$ day with risperidone has been reported to successfully reverse risperidone-induced hyperprolactinemia. The association between aripiprazole dose and prolactin level when used as adjunctive treatment needs to be more fully evaluated.

\section{Author details}

${ }^{1}$ Social Insurance Institute, Analipsi, Thessaloniki, Greece. ${ }^{2} 1$ st and 5 th Department, Dromokaition Psychiatric Hospital, Athens, Greece. ${ }^{3}$ Psychiatric Clinic, General Hospital of Chania, Greece.

Published: 22 April 2010

\section{References}

1. Lee B-H, Kim Y-K, Park S-H: Using aripiprazole to resolve antipsychoticinduced symptomatic hyperprolactinemia: a pilot study. Progress in Neuro-Psychopharmacology \& Biological Psychiatry 2006, 30:714-7.

2. Paulzen $M$, Gründer $G$ : Amisulpride-induced hyperprolactinemia is not reversed by addition of aripiprazole. Int I Neuropsychopharmacol 2007, 10:149-51

3. Shim J-C, Shin KJ-G, Kelly DL, Jung D-U, Seo Y-S, Shon J-H, Conley R: Adjunctive treatment with a dopamine partial agonist, aripiprazole, for antipsychotic-induced hyperprolactinemia: a placebo-controlled trial. Am J Psychiatry 2007, 164(9):1404-1410.

doi:10.1186/1744-859X-9-S1-S164

Cite this article as: Kotorki et al:: Reversal of symptomatic antipsychoticinduced hyperprolactinemia with addition of aripiprazole. Annals of General Psychiatry 2010 9(Suppl 1):S164.

\section{Submit your next manuscript to BioMed Central} and take full advantage of:

- Convenient online submission

- Thorough peer review

- No space constraints or color figure charges

- Immediate publication on acceptance

- Inclusion in PubMed, CAS, Scopus and Google Scholar

- Research which is freely available for redistribution

Submit your manuscript at www.biomedcentral.com/submit 